Qian, S., Miao, C., and Humphrey, RH. (2021). The basic income and prospect theory: implications for the field of entrepreneurship. Industrial and Organizational Psychology, 14(4), 605-608. https://doi.org/10.1017/iop.2021.104

Author accepted copy:

\title{
The Basic Income and Prospect Theory: Implications for the Field of Entrepreneurship
}

Hüffmeier and Zacher (2021), in their focal article, discussed the promise for the field of industrial, work, and organizational psychology to examine the topic of the basic income. One typically asked question as discussed in their article is whether the basic income will encourage more people to become entrepreneurs. Hüffmeier and Zacher (2021) indicated that the basic income may provide individuals a choice to leave the labor market to take entrepreneurial risks; it also provides those having limited economic resources with a financial buffer to encourage entrepreneurship activities. The rise of the psychology of entrepreneurship has strengthened and enriched the field of individual and organizational (I-O) psychology (Frese \& Gielnik, 2014). Likewise, investigating the effect of the basic income on entrepreneurship has high topical relevance to the field of industrial, work, and organizational psychology. In this commentary, we expanded on the discussion by Hüffmeier and Zacher (2021) regarding the effect of the basic income on entrepreneurship. Specifically, we built on prospect theory to present a two by two matrix to unravel the complexities underlying the effect of the basic income on entrepreneurship. We also discussed future directions and provided some recommendations for researchers and practitioners to develop some joint efforts in order to address the topic of the basic income.

\section{Prospect Theory}


Prospect theory suggested that individuals are inclined to be loss averse; specifically, they consider the displeasure of losses to be more pronounced than the pleasure of equal gains. Consequently, decision-makers may even forsake the opportunity of possible gains if pursuing them entails some potential for losses compared to their current position (Holmes et al., 2011; Kahneman \& Tversky, 1979; Zhang et al., 2008). Namely, this theory indicates that individuals just do not like to lose (Holmes et al., 2011), and individuals' apprehension about losses relative to their existing wealth will affect their decision making (Zhang et al., 2008). Startups are known to have a high failure rate (Shane, 2008), and the entrepreneurial career is filled with risks and uncertainties because being an entrepreneur may put one's financial status, well-being, and career prospects at risk (Brockhaus, 1980).

Taken altogether, we argue that whether the basic income will motivate individuals to engage in entrepreneurship may also depend on other factors which will influence their chance for potential losses relative to their existing wealth. Two factors which are known to impact one's decision to engage in entrepreneurship are employment status of individuals and unemployment rate of a labor market (Shane, 2008).

\section{Employment Status and Unemployment Rate}

We proposed a two by two matrix in order to better clarify the joint effect of the basic income, employment status, and unemployment rate on entrepreneurship (see Figure 1). This matrix presents four different scenarios which show the level of impact of the basic income on one's likelihood to engage in entrepreneurship.

Insert Figure 1 about here 


\section{Scenario \#1}

The individuals in this scenario are employed and work in a labor market having a low unemployment rate. We avow that the individuals in this scenario are very unlikely to be motivated by the basic income to engage in entrepreneurship because engaging in entrepreneurship may require them to forgo their current pay and benefits, secured job status, and career opportunities. To minimize the chance to lose, the individuals in this scenario should have a higher proclivity to stay in the labor market in spite of the provision of the basic income.

\section{Scenario \#2}

The individuals in this scenario are employed and work in a labor market having a high unemployment rate. Compared to the individuals in Scenario \#1, the individuals in Scenario \#2 may have a somewhat higher propensity to engage in entrepreneurship as motivated by the basic income. It may sound tempting for employed individuals to stay in their job when unemployment rate is high. Alternative job opportunities may be limited in the labor market due to high unemployment rate. In addition, high unemployment rate in the labor market sends an alarming signal to employed individuals that their job may also be insecure and that it is challenging for them to quickly find another equivalent job in the event of being laid off, which may put them in a loss situation. Therefore, there may be a higher likelihood for employed individuals in Scenario \#2 to capitalize on the basic income to start entrepreneurial activities in order to protect them from going to a loss situation (e.g., unexpectedly being laid off). This is consistent with prospect theory which postulates that individuals are prone to take risks in the context of loss situations (Zhang et al., 2008).

\section{Scenario \#3}


The individuals in this scenario are unemployed, and the labor market has a low unemployment rate. Compared to the individuals in the first two scenarios, the basic income may have a moderate level of effect to motivate the individuals in Scenario \#3 to engage in entrepreneurship. Due to low unemployment rate in the labor market, individuals may be prone to find jobs in the labor market rather than take risks to become entrepreneurs and face potential losses. In spite of their somewhat higher propensity to enter into the labor market, unemployed individuals are still greater than twice as likely as employed individuals to create their own businesses according to prior research (Shane, 2008). This coincides with prospect theory because using the basic income to start up a business may enable unemployed individuals to grow their personal wealth, thus helping them recover their position and stem the losses as a result of unemployment.

\section{Scenario \#4}

The individuals in this scenario are unemployed, and the labor market has a high unemployment rate. Relative to the individuals in the other three scenarios, the basic income may have the strongest impact on motivating the individuals in Scenario \#4 to engage in entrepreneurship. Due to the lack of job opportunities in the labor market, unemployed individuals may struggle to find a job. Hence, these unemployed individuals are very likely to rely on the basic income to initiate businesses in order to rectify their loss situations. Since it does not take much money to initiate a business (Shane, 2008), the relative ease of business creation may further prompt unemployed individuals to use the basic income to become entrepreneurs rather than painstakingly hunt for a job in a highly competitive labor market having few job opportunities.

\section{Future Directions and Recommendations}


This commentary presents a two by two matrix and some testable propositions which may pave the way for future research to make theoretical and practical contributions on the topic of the basic income. I-O psychologists and entrepreneurship scholars should work together to better understand the effects of the basic income on entrepreneurial processes, and this increased understanding should help them make better policy recommendations. I-O psychologists and entrepreneurship scholars may also organize conferences, meetings, workshops, seminars, and training sessions to not only discuss the research opportunities and practical implications of this research. These meetings should include policy makers and key decision-makers who can develop and implement effective policies and practices to maximize the benefits and minimize the pitfalls of the basic income. I-O psychologists may serve as mentors to better guide the general population regarding how to make better use of the basic income to live a worthwhile, meaningful, and productive life. We argue that accomplishing these objectives will help to address the concerns regarding the basic income as discussed in Hüffmeier and Zacher (2021).

The Society for Industrial and Organizational Psychology (SIOP) can be an important venue where a majority of the above-mentioned activities can be initiated. The SIOP members may consider building task forces, tracks, professional development workshops, and/or symposiums to engage both academic researchers and practitioners in the conversation in order to develop synergistic efforts to address the topic of the basic income.

\section{References}

Brockhaus, R. H. (1980). Risk taking propensity of entrepreneurs. Academy of Management Journal, 23(3), 509-520. 
Holmes, R. M., Bromiley, P., Devers, C. E., Holcomb, T. R., \& McGuire, J. B. (2011). Management theory applications of prospect theory: Accomplishments, challenges, and opportunities. Journal of Management, 37(4), 1069-1107.

Hüffmeier, J., \& Zacher, H. (2021). The basic income: Initiating the needed discussion in industrial, work, and organizational psychology. Industrial and Organizational Psychology: Perspectives on Science and Practice.

Kahneman, D., \& Tversky, A. (1979). Prospect theory: An analysis of decision making under risk. Econometrica, 42, 262-291.

Shane, S. A. (2008). The illusions of entrepreneurship: The costly myths that entrepreneurs, investors, and policy makers live by. New Haven: Yale University Press.

Zhang, X., Bartol, K. M., Smith, K. G., Pfarrer, M. D., \& Khanin, D. M. (2008). CEOs on the edge: Earnings manipulation and stock-based incentive misalignment. Academy of Management Journal, 51(2), 241-258. 
Figure 1. The Basic Income, Employment Status, Unemployment Rate, and Their Joint Effect on

\section{Entrepreneurship}

\section{Unemployed Individuals}

Employed Individuals

\begin{tabular}{|l|l|}
\hline $\begin{array}{l}\text { Scenario \#3 } \\
\text { The basic income will have moderate } \\
\text { level of effect to motivate unemployed } \\
\text { individuals to engage in } \\
\text { entrepreneurship. }\end{array}$ & $\begin{array}{l}\text { Scenario \#4 } \\
\text { The basic income will have the } \\
\text { strongest effect to motivate unemployed } \\
\text { individuals to engage in } \\
\text { entrepreneurship. }\end{array}$ \\
\hline $\begin{array}{l}\text { Scenario \#1 } \\
\text { The basic income will have weak effect } \\
\text { to motivate employed individuals to } \\
\text { engage in entrepreneurship. }\end{array}$ & $\begin{array}{l}\text { The basic income will have low to } \\
\text { moderate level of effect to motivate } \\
\text { employed individuals to engage in } \\
\text { entrepreneurship. }\end{array}$ \\
\hline
\end{tabular}

Low Unemployment Rate 